\title{
PARTIAL FRACTIONATION AND CHARACTERIZATION OF NUCLEAR PROTEIN KINASES IN HeLa $S_{3}$ CELLS
}

\author{
JUDITH A. THOMSON, MANUEL J. MON, JANET L. STEIN*, KATHRYN A. DUVAL, \\ LEWIS J. KLEINSMITH** and GARY S. STEIN
}

Department of Biochemistry and Molecular Biology, University of Florida, Gainesville, FL 3210. *Department of Immunology and Medical Microbiology, **Department of Zoology, University of Michigan, Ann Arbor, MI 48104 (U.S.A.)

Accepted April 28th, 1979

Five fractions of phosphoprotein kinase activity were separated by phosphocellulose chromatography of nuclear non-histone phosphoproteins isolated from exponentiallygrowing HeLa $\mathrm{S}_{3}$ cells. Each fraction contained a heterogeneous group of proteins and possibly more than one protein kinase. These fractions were characterized with respect to specific activity and optimal concentrations of $\mathrm{Mg}^{2+}$ and $\mathrm{Mn}^{2+}$. The ability of each kinase fraction to catalyze the incorporation of ${ }^{32} \mathrm{P}$ from $\left[\gamma^{32} \mathrm{P}\right] \mathrm{ATP}$ into various molecular weight classes of heat-inactivated non-histone nuclear phosphoproteins (as substrate) was examined by electrophoretically resolving the proteins in SDS-polyacrylamide gels. Each kinase fraction induced a distinctive pattern of protein phosphorylation. Substrate preferences (non-histone phosphoprotein or histone) were determined for each fraction by examining the incorporation of ${ }^{32} \mathrm{P}$ from $\left[\gamma^{32} \mathrm{P}\right] \mathrm{ATP}$ in to both TCA-precipitable material and into specific molecular weight classes of proteins. The activities of two of the fractions to phosphorylate non-histone nuclear phosphoprotein were stimulated by the presence of histones. Studies were undertaken to assess the effects of cAMP or cGMP on the activity of each kinase fraction. No significant sensitivity to the cyclic nucleotides was observed for any of the kinase fractions.

The underlying mechanisms involved in the control of gene expression in eukaryotic systems still remain obscure, although several lines of evidence suggest control of gene readout may in part be attributable to components of the non-histone nuclear proteins $[1,2]$. The nuclear proteins are highly phosphorylated and numerous correlations exist between changes in the metabolism of phosphoproteins and modifications in gene expression in a broad spectrum of biological situations [3-11]. Such modifications in phosphoprotein metabolism include changes in the extent of phosphorylation, alterations in the phosphorylation of specific polypeptides and variations in the synthesis and turnover of phosphoproteins. Results from chromatin reconstitution experiments suggest an important role for nonhistone chromosomal protein phosphorylation in the control of transcription $[12,13]$.

Phosphorylation and dephosphorylation of nuclear proteins are reactions 
enzymatically catalyzed by nuclear protein kinases and phosphatases $[4,7,11,14-24]$. Therefore, understanding the properties of these enzymes should enhance our understanding of the mechanisms by which phosphorylation of chromosomal proteins may modulate gene function. In this paper we report initial results from studies directed towards characterization of nuclear protein kinase in extronentially-growing $\mathrm{HeLa} \mathrm{S}_{3}$ cells.

\section{MATERIALS AND METHODS}

Cells. HeLa $\mathrm{S}_{3}$ cells were grown in suspension culture in Joklik-modified Eagle's minimal essential medium supplemented with $7 \%$ calf serum. To maintain exponential growth the cell concentration was kept between $2 \times 10^{5}-5 \times 10^{5}$ cells $/ \mathrm{ml}$. Most experiments required approx. $6 \times 10^{9}$ cells.

Isolation of nuclei. Isolation and preparation of nuclear protein kinase fractions were carried out at $4^{\circ} \mathrm{C}$. Cells were harvested by centrifugation at $600 \mathrm{~g}$ for $4 \mathrm{~min}$ and washed three times in Earle's balanced salt solution. The cell pellet was homogenized by $30--35$ strokes with a motor-driven teflon pestle in 10 vols. of $2.2 \mathrm{M}$ sucrose $/ 1 \mathrm{mM} \mathrm{MgCl}$. The mixture was then diluted to $1.8 \mathrm{M}$ sucrose with $1 \mathrm{mM} \mathrm{MgCl}_{2}$ and after thorough homogenization was centrifuged at $80000 \mathrm{~g}$ for $1 \mathrm{~h}$. The resulting nuclear pellet was homogenized in $0.14 \mathrm{M} \mathrm{NaCl}$ and centrifuged at $8000 \mathrm{~g}$ repeatedly until the nuclei appeared free of cytoplasmic material when examined by phase contrast microscopy.

Isolation of nuclear phosphoproteins. Purified nuclei at a DNA concentration of $2 \mathrm{mg} / \mathrm{ml}$ were vigorously homogenized in a Dounce homogenizer (using a B pestle) in $1.0 \mathrm{M} \mathrm{NaCl} / 0.05 \mathrm{M}$ Tris ( $\mathrm{pH} 7.5$ ). 1.5 volumes of $0.02 \mathrm{M}$ Tris $(\mathrm{pH} 7.5)$ were added dropwise, and the mixture was briefly homogenized and then centrifuged at $80000 \mathrm{~g}$ for $1 \mathrm{~h}$. The proteins in the supernatant were treated with BioRex 70 (previously equilibrated with $0.4 \mathrm{M} \mathrm{NaCl} / 0.02 \mathrm{M}$ Tris, $\mathrm{pH} \mathrm{7.5)}$ at a ratio of $20 \mathrm{mg}$ BioRex $/ \mathrm{mg}$ protein. The suspension was stirred for 5-10 min and centrifuged at $6000 \mathrm{~g}$ for 5 min. Calcium phosphate gel (prepared according to the method of Keilen and Hartree [25]) was added to the resulting supernatant at a ratio of $0.45 \mathrm{mg} \mathrm{gel} / \mathrm{mg}$ protein; the mixture was stirred for $5-10 \mathrm{~min}$ and centrifuged at $6000 \mathrm{~g}$ for $5 \mathrm{~min}$. The pellet of calcium phosphate gel was washed in $40 \mathrm{ml}$ of $1.0 \mathrm{M}\left(\mathrm{NH}_{4}\right) \mathrm{SO}_{4} / 0.05 \mathrm{M}$ Tris $(\mathrm{pH} 7.5)$ and solubilized in $0.3 \mathrm{M}$ EDTA $(\mathrm{pH} 7.5) / 0.33 \mathrm{M}\left(\mathrm{NH}_{4}\right) \mathrm{SO}_{4}$ at a ratio of $0.2 \mathrm{ml}$ of solution $/ \mathrm{mg}$ gel. The insoluble residue was removed by centrifugation for $15 \mathrm{~min}$ at $33000 \mathrm{~g}$; the supernatant consisted of the protein fraction referred to as 'total phosphoproteins'. These proteins were dialyzed against several changes of $0.05 \mathrm{M}$ Tris $(\mathrm{pH} 7.5) / 0.1 \mathrm{M} \mathrm{NaCl}$.

Separation of nuclear protein kinase fractions. Three milligrams of total phosphoprotein from HeLa cell nuclei were applied to a phosphocellulose 
column $(0.9 \mathrm{~cm} \times 14 \mathrm{~cm})$ that had been previously equilibrated overnight with $0.05 \mathrm{M}$ Tris ( $\mathrm{pH} 7.5) / 0.1 \mathrm{M} \mathrm{NaCl}$. The column was then eluted stepwise with $0.05 \mathrm{M}$ Tris (pH 7.5) containing $0.1,0.3,0.5,0.7$ and $0.9 \mathrm{M} \mathrm{NaCl}$. Twenty 1-ml fractions were collected with each buffer elution of the column. The first fractions eluted at $0.1 \mathrm{M} \mathrm{NaCl}$ represent protein which does not bind to the column (flowthrough). The optical density of the eluted fractions was measured and 5 distinct peaks of protein were resolved. The fractions constituting each peak were pooled and dialyzed overnight against 100 vols. of $0.05 \mathrm{M}$ Tris $(\mathrm{pH} 7.5)$. It should be noted that each protein kinase fraction is a heterogeneous group of proteins and may contain more than one species of protein kinase. Further characterization of the protein kinase fractions was performed as described in Results.

Preparation of protein kinase modulator. Crude protein kinase modulator was prepared from dog heart by the method of Appleman [26]. Fifty grams of dog heart were minced and then homogenized in a Tekmar homogenizer at full speed. The homogenate was centrifuged at $15000 \mathrm{~g}$ for $15 \mathrm{~min}$ and the supernatant was collected. The tissue extrart was boiled with stirring for $20 \mathrm{~min}$, cooled in ice and subsequently filtered through three layers of cheesecloth. One-ninth volume of 50\% TCA (trichloroacetic acid) was added to the filtrate and the resultant precipitate was collected by centrifugation at $15000 \mathrm{~g}$ for $15 \mathrm{~min}$. The precipitate was solubilized in double-distilled $\mathrm{H}_{2} \mathrm{O}$, the $\mathrm{pH}$ was adjusted to 7.5 with $5 \mathrm{~N} \mathrm{NaOH}$ and the solution was dialy zed overnight against 100 vols. of distilled $\mathrm{H}_{2} \mathrm{O}$ at room temperature. The solution was then centrifuged at $15000 \mathrm{~g}$ for $15 \mathrm{~min}$. The supernatant was collected and is referred to as 'crude protein kinase modulator'.

Protein kinase activity assay. Each assay contained the following (unless otherwise indicated) in a total volume of $0.3 \mathrm{ml}: 0.05 \mathrm{M}$ Tris $(\mathrm{pH} 8.0$ ), $20 \mathrm{mM} \mathrm{MgCl} 2,0.20 \mathrm{ml}$ protein kinase fraction; $6 \mathrm{nmol}\left[\gamma-{ }^{32} \mathrm{P}\right]$ ATP (spec. act. $0.5 \mathrm{Ci} / \mathrm{nmol} \mathrm{ATP}$ made according to the procedure described by Glynn and Chappell [27]) and when indicated, $5 \mu \mathrm{M}$ cAMP, $5 \mu \mathrm{M}$ cGMP, $40-100 \mu \mathrm{g}$ heated total phosphoproteins, $50-130 \mu \mathrm{g}$ histone or $60 \mu \mathrm{g}$ protein kinase modulator. The assay mixtures were incubated for $10 \mathrm{~min}$ at $37^{\circ} \mathrm{C}$ and the reaction was terminated by the addition of $2 \mathrm{ml}$ of $10 \%$ TCA $/ 2 \%$ sodium pyrophosphate. Four milligrams of bovine serum albumin were added as carrier and the mixtures were extensively vortexed and then centrifuged at $900 \mathrm{~g}$ for $3 \mathrm{~min}$. The pellets were washed three times (by vortexing and centrifugation) in $12 \mathrm{ml}$ of $5 \% \mathrm{TCA} / 1 \%$ sodium pyrophosphate. The final pellet was solubilized in $0.5 \mathrm{ml}$ of NCS reagent (Amersham Corp.), $3 \mathrm{ml}$ of dioxane-toluene scintillation fluid ( $150 \mathrm{ml}$ liquiflour; $1 \mathrm{l}$ toluene, $1 \mathrm{l}$ ethanol; 11 dioxane; $240 \mathrm{~g}$ napthalene) were added and incorporation of ${ }^{32} \mathrm{P}$ was measured by liquid scintillation spectrometry.

Examination of ${ }^{32} \mathrm{P}$ incorporation into phosphoproteins utilizing polyacrylamide gel electrophoresis. To determine the ability of protein kinase 
fractions to in corporate ${ }^{32} \mathrm{P}$ into nuclear phosphoproteins, each fraction was incubated with $\left[\gamma-{ }^{32} \mathrm{P}\right] \mathrm{ATP}$ and exogenous substrate consisting of heatinactivated phosphoproteins from exponentially-growing HeLa cells. The phosphorylated substrate was then examined by polyacrylamide gel electrophoresis. Since it was not possible to remove the small quantity of endogenous substrate contained in each fraction, a large amount $(150 \mu \mathrm{g}$; 20 -100-fold excess) of endogenous substrate was used to dilute the endogenous protein.

Each protein kinase fraction was assayed in the following mixture with a total volume of $0.3 \mathrm{ml}: 0.05 \mathrm{M}$ Tris $(\mathrm{pH} 8.0) / 20 \mathrm{mM} \mathrm{MgCl}_{2} / 0.20 \mathrm{ml}$ protein kinase fraction $/ 6 \mathrm{nmol}\left[\gamma_{-}{ }^{32} \mathrm{P}\right] \mathrm{ATP}$ (spec. act. of $0.5 \mathrm{Ci} / \mathrm{nmol} \mathrm{ATP}$ ) and $100-150 \mu \mathrm{g}$ of heat-inactivated total nuclear phosphoproteins from HeLa cells. The assay mixtures were incubated for $10 \mathrm{~min}$ at $37^{\circ} \mathrm{C}$ and the reaction was terminated by the addition of solid urea to a final concentration of $5 \mathrm{M}$ and then extensively dialyzed against either $0.1 \%$ sodium dodecyl sulfate (SDS) $/ 10 \mathrm{mM}$ sodium phosphate $(\mathrm{pH} 7.0) / 0.1 \% \beta$-mercaptoethanol or $0.0675 \mathrm{M}$ Tris $/ 0.1 \% \mathrm{SDS} / 0.1 \% \quad \beta$-mercaptoethanol $(\mathrm{pH} 6.8)$. Details of the electrophoresis procedures used in these studies are given in the legend of Figs. 2 and 4 . The data are presented as percent of total radioactivity, reflecting the relative extent of phosphorylation of various molecular weight classes of non-histone chromosomal polypeptides. Listed in each legend are the counts per minute represented by $1 \%$ total counts.

\section{RESULTS}

The starting material we have been using for the isolation and separation of protein kinase activity in HeLa $\mathrm{S}_{3}$ cells is a nuclear phosphoprotein fraction prepared by a procedure developed by Langan [28]. This fraction of nuclear proteins has been shown to be rich in phosphorus-containing proteins and endogenous protein kinase activity $[18,28]$ and does not contain significant levels of phosphatase or protease activity (unpublished observations). It is this protein fraction which several laboratories have used to study the correlation between phosphorylation of non-histone chromosomal proteins and variations in gene expression in many biological systems $[5,8,12,13,18,23,29]$. These nuclear phosphoproteins can be resolved into several distinct protein kinase fractions. Kish and Kleinsmith [18], using a gradient elution procedure, obtained 12 protein kinase fractions from calf thymus and Thomson et al. [23], using a batch elution procedure, obtained 6 reproducible fractions from several neoplastic tissues. Both elution techniques yield fractions containing multiple species of protein and perhaps more than one protein kinase.

By applying 'total phosphoproteins' isolated from nuclei of exponentiallygrowing HeLa cells to a phosphocellulose column and eluting with buffers containing 5 stepwise increases in $\mathrm{NaCl}$ concentration $(0.1 \mathrm{M}, 0.3 \mathrm{M}, 0.5 \mathrm{M}$, $0.7 \mathrm{M}, 0.9 \mathrm{M} \mathrm{NaCl}$ ), it was possible to subdivide the HeLa phosphoproteins 


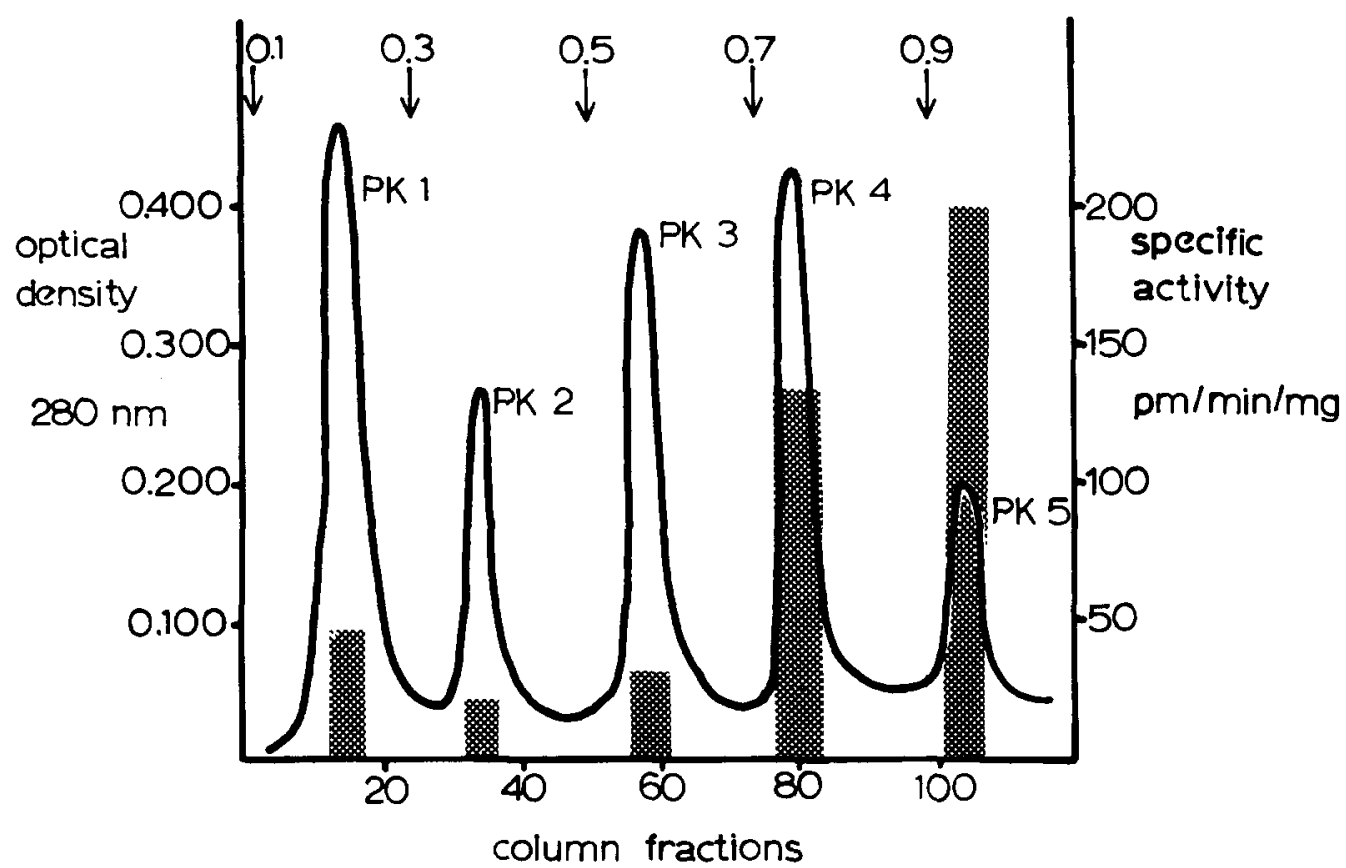

Fig. 1. Absorption profile of nuclear phosphoproteins and specific activity of protein kinase activity eluted from phosphocellulose. Total phosphoproteins from HeLa cell nuclei were applied to a phosphocellulose column and eluted as described in Materials and Methods. The resulting absorption profile of the eluted fractions and the specific activity of each peak is shown ( $\mathrm{pmol} / \mathrm{min} / \mathrm{mg}$ protein). Protein concentrations were determined by the method of Layne [51].

into 5 reproducible fractions of protein kinase activity. The 5 fractions were defined both by absorbance at $280 \mathrm{~nm}$ and by protein kinase activity assayed using endogenous phosphoprotein as substrate. Fifty-eight percent (58\%) of the applied total protein kinase activity was recovered in the 5 eluted peaks. Peaks $1-5$ accounted for $5 \%, 4.4 \%, 18.8 \%, 48.3 \%$ and $23.2 \%$ respectively, of the recovered activity. Figure 1 shows a typical absorbance and specific activity profile of nuclear phosphoproteins eluted from a phosphocellulose column. As is evident from Fig. 1, peak 4 represents the highest percentage of recovered activity $(48.3 \%)$ and peak 5 contains the highest specific activity ( $194 \mathrm{pmol}$ phosphate incorporated $/ \mathrm{min} / \mathrm{mg}$ protein). Several characteristics of these 5 electrophoretically heterogenous fractions, perhaps each containing more than one kinase, were then investigated, both to determine if each fraction contained unique species of kinase activity and to define the properties of these fractions. Each fraction was assayed in the presence of varying concentrations of $\mathrm{Mg}^{2+}$ and $\mathrm{Mn}^{2+}$ and the optimal concentrations for each peak were determined by the incorporation of ${ }^{32} \mathrm{P}$ from $\left[\gamma^{32} \mathrm{P}\right] \mathrm{ATP}$ into TCA precipitable material, using endogenous 


\section{TABLE I}

\section{CHARACTERISTICS OF PROTEIN KINASE FRACTIONS FROM HeLa CELL NUCLEI}

All assays were performed as described in Materials and Methods. Optimal conditions were determined by the concentration that resulted in the highest incorporation of ${ }^{32} \mathbf{P}$ into TCA-insoluble material. Ranges of concentrations tested are as follows: $\mathrm{pH}, 5.0-9.0$; $\mathrm{Mg}^{2+}, 10-50 \mathrm{mM} ; \mathrm{Mn}^{2+}, 0.4-2.0 \mathrm{mM}$. No kinase activity was demonstrated in the absence of $\mathrm{Mg}^{2+}$ and $\mathrm{Mn}^{2+}$. Added substrate (line 4) was $40 \mu \mathrm{g}$ histone plus $40 \mu \mathrm{g}$ phosphoprotein. All assays were done in duplicate and all values are the average of at least three experiments. Percentage of control values (lines 8, 9 and 10) were determined by assaying the fraction in the presence of $\left[\gamma^{-32} \mathrm{P}\right]$ ATP with or without added protein $(40 \mu \mathrm{g}$ histone or $40 \mu \mathrm{g}$ phosphoprotein) and dividing the counts incorporated in the presence of the added protein by the counts incorporated in its absence. Blank assays (containing all components except the kinase fraction) were $200-600 \mathrm{cpm}$ and assays containing kinase fractions were at least $6^{--10}$ times higher in incorporated radioactivity than blank assays.

\begin{tabular}{|c|c|c|c|c|c|c|c|}
\hline & & \multicolumn{6}{|l|}{ Fraction } \\
\hline & & \multirow{2}{*}{$\begin{array}{l}\text { Total } \\
\text { phospho- } \\
\text { protein }\end{array}$} & \multicolumn{5}{|c|}{ Protein kinase fraction } \\
\hline & & & 1 & 2 & 3 & 4 & 5 \\
\hline 1 & $\begin{array}{l}\mathrm{NaCl} \text { concentration } \\
\text { of elution buffer }(\mathrm{M})\end{array}$ & - & 0.1 & 0.3 & 0.5 & 0.7 & 0.9 \\
\hline 2 & Spec. act. (pmol/min/mg) ${ }_{\mathrm{B}^{\mathrm{b}}}^{\mathrm{A}^{\mathrm{a}}}$ & $\stackrel{535}{-}$ & $\begin{array}{l}45.0 \\
66.1\end{array}$ & $\begin{array}{l}16.1 \\
23.7\end{array}$ & $\begin{array}{l}30.8 \\
47.1\end{array}$ & $\begin{array}{l}132 \\
232\end{array}$ & $\begin{array}{l}194 \\
725\end{array}$ \\
\hline 3 & $\begin{array}{l}\% \text { of total recovered } \\
\text { activity assayed with } \\
\text { endogenous substrate }\end{array}$ & 100 & $\begin{array}{c}5 \\
\text { (range } \\
2-10)\end{array}$ & $\begin{array}{l}4.4 \\
\text { (range } \\
2-7 \text { ) }\end{array}$ & $\begin{array}{c}18.8 \\
\text { (range } \\
10-30 \text { ) }\end{array}$ & $\begin{array}{l}48.3 \\
\text { (range } \\
32-67 \text { ) }\end{array}$ & $\begin{array}{l}23.2 \\
\text { (range } \\
18-40 \text { ) }\end{array}$ \\
\hline 4 & $\begin{array}{l}\% \text { of total recovered } \\
\text { activity assayed with } \\
\text { added substrate }\end{array}$ & 100 & 5.4 & 3.3 & 7.4 & 30.9 & 50.6 \\
\hline 5 & Optimal pH & 8.0 & - & - & - & - & - \\
\hline 6 & Optimal $\mathbf{M g}^{2+}$ & 20 & 15 & 25 & 15 & 40 & $25-30$ \\
\hline 7 & Optimal $\mathrm{Mn}^{2+}$ & 1.6 & 1.4 & 1.4 & 1.6 & 1.6 & 1.4 \\
\hline 8 & $\begin{array}{l}\% \text { activity retained } \\
\text { when } \mathrm{Mg}^{2+} \text { replaced } \\
\text { with } \mathrm{Mn}^{2+}\end{array}$ & 90 & 115 & 86 & 37 & 13 & 6 \\
\hline 9 & $\begin{array}{l}\% \text { of control with the } \\
\text { addition of histone }\end{array}$ & - & 755 & 183 & 106 & 104 & 54 \\
\hline 10 & $\begin{array}{l}\% \text { of control with the } \\
\text { addition of heat- } \\
\text { inactivated phospho- } \\
\text { protein }\end{array}$ & - & 335 & 188 & 194 & 300 & 186 \\
\hline
\end{tabular}

\footnotetext{
${ }^{a} \mathrm{~A}=$ endogenous protein

b $\mathrm{B}=$ added protein
} 
substrate. Table I lists the results of these studies and indicates that the 5 protein kinase peaks have optimal $\mathrm{Mg}^{2+}$ concentrations of $15,25,15,40$ and $2530 \mathrm{mM}$ respectively and optimal $\mathrm{Mn}^{2+}$ concentrations of $1.4,1.4$, $1.6,1.6$ and $1.4 \mathrm{mM}$.

The substrate specificity of each of the kinase fractions was then examined. Both histones and non-histone chromosomal proteins were assayed for their abilities to serve as substrates. A complicating factor in investigating the non-histone protein substrate specificity is that each protein kinase fraction contains endogenous phosphoprotein that can be utilized as substrate and this endogenous protein is not identical in each fraction. Therefore, to determine any difference in the specificity of non-histone protein phosphorylation by the protein kinase fractions, it was necessary to provide an excess of the same exogenous substrate to each of the fractions to dilute the contribution of the endogenous protein substrate as much as possible. The exogenous substrate used to assay the kinase fractions was 'total phosphoprotein' which had been heated at $60^{\circ} \mathrm{C}$ for $10 \mathrm{~min}$ to eliminate greater than $95 \%$ of the endogenous protein kinase activity. After incubation with the kinase fraction the heat-inactivated phosphoproteins were examined by SDS-polyacrylamide gel electrophoresis, and the distribution of ${ }^{32} \mathrm{P}$ radioactivity among the various molecular weight classes of phosphoproteins was determined. As is shown in Fig. 2, each protein kinase fraction exhibits a different pattern of protein phosphorylation. All kinase fractions phosphorylated nuclear proteins which electrophoresed in the 100000--150000 molecular weight region of the gel, however, substantial increases can be seen in the phosphorylation of lower molecular weight (35000-55000) proteins by fraction 3 , and in the intermediate molecular weight $(55000-100000)$ proteins by fraction 4 . In addition, fraction 5 exhibits decreased phosphorylation of a high molecular weight protein band as compared with the other four fractions.

The protein kinase fractions were also examined for their preference for either heat-inactivated phosphoproteins or histones as substrates. In this determination two methods were employed. The first was a comparison of the incorporation of ${ }^{32} \mathrm{P}$ into TCA-insoluble material of each fraction utilizing endogenous protein, heat-inactivated phosphoprotein, or histone as substrate (Table I). Protein kinase peak 1 showed a higher percentage increase of kinase activity when histone, as compared with added heatinactivated phosphoprotein, was added as exogenous substrate. Protein kinase peak 2 showed approximately equal increases of activity when either histone or phosphoprotein was added as compared with endogenous substrate. Protein kinase peaks 3, 4 and 5 showed a greater increase when her.t inactivated phosphoproteins, as compared with histones, were added, suggesting that these three protein kinase fractions preferentially use non-histone proteins as substrates.

An important question which arose was whether the histones themselves were acting as substrate or whether they were stimulating the phosphoryla- 


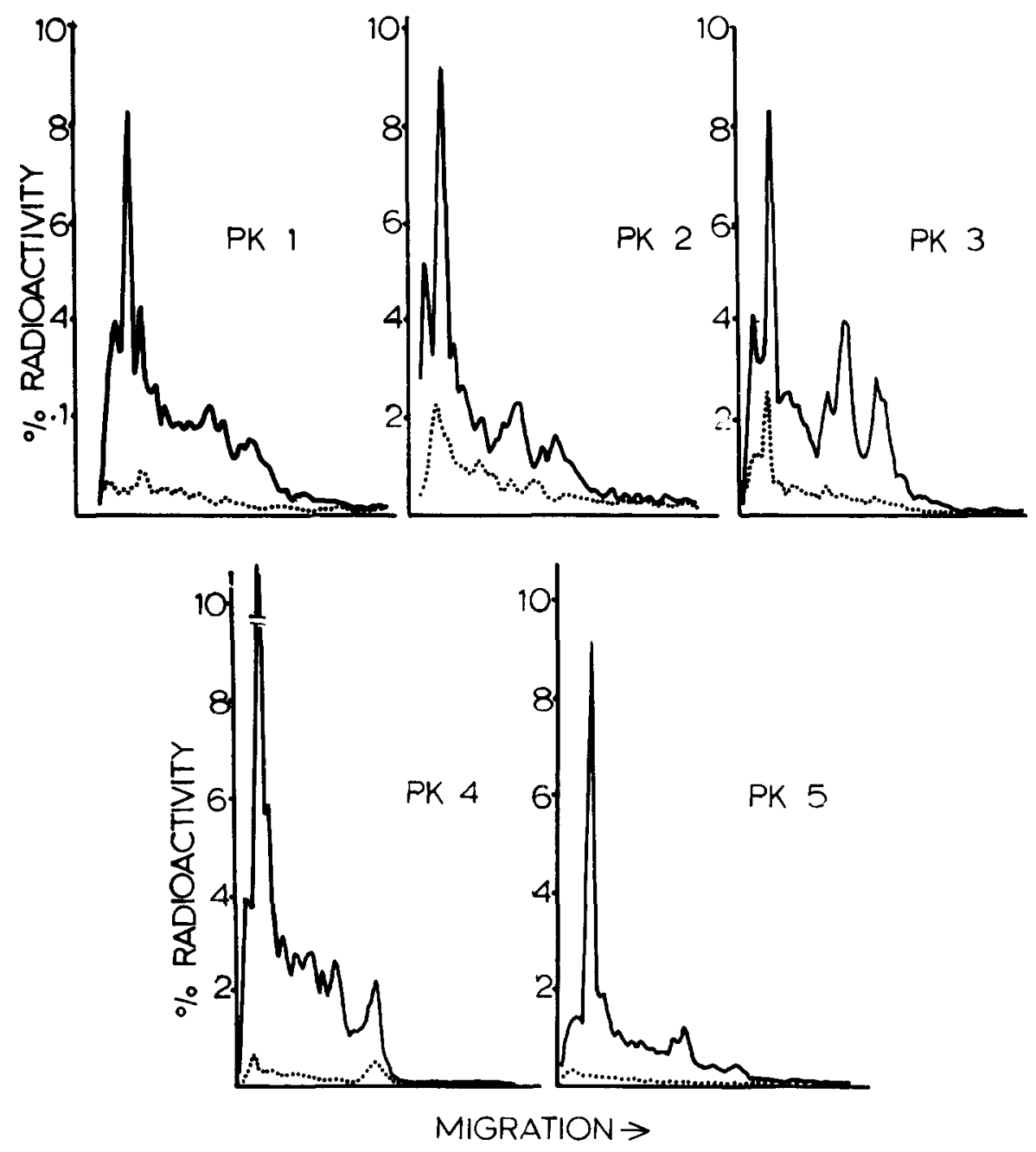

Fig. 2. Distribution of ${ }^{32} \mathrm{P}$ among nuclear phosphoproteins induced by each isolated protein kinase fraction. Each protein kinase fraction was assayed in the presence of $\left[\gamma^{32} \mathrm{P}\right] \mathrm{ATP}$ and exogenous substrate (heat-inactivated phosphoproteins) as described in Materials and Methods. After termination of the reaction by the addition of solid urea to a final concentration of $5 \mathrm{M}$, the reaction mixtures were dialyzed extensively against $0.1 \%$ SDS $/ 0.01 \mathrm{M} \mathrm{NaPO}_{4}(\mathrm{pH} 7.0) / 0.1 \% \beta$-mercaptoethanol, and subsequently fractionated electrophoretically according to molecular weight on $7.5 \%$ acrylamide, $0.28 \%$ bisacrylamide gels according to the procedure previously reported [9,52]. Electrophoresis was for $6.5 \mathrm{~h}$ at $8 \mathrm{~mA}$ per gel. The gels were fixed overnight in $12.5 \%$ trichloroacetic acid $/ 7 \%$ acetic acid $/ 40 \%$ ethanol, and stained in $0.25 \%$ Coomassie brilliant blue in the above solution for $5 \mathrm{~h}$. After the gels were destained in a solution of $7 \%$ acetic acid $110 \%$ ethanol and scanned at $590 \mathrm{~nm}$, the gels were sectioned into $1-\mathrm{mm}$ slices and each slice examined for the incorporation of ${ }^{32} \mathrm{P}$. The dotted lines represent the ${ }^{32} \mathrm{P}$ incorporated into the endogenous substrate when no additional protein was added as substrate to the assay mixtures. PK 1-PK 5 represent protein kinase fractions eluted from phosphocellulose with $0.1,0.3,0.5,0.7$ and $0.9 \mathrm{M} \mathrm{NaCl}$, respectively. 


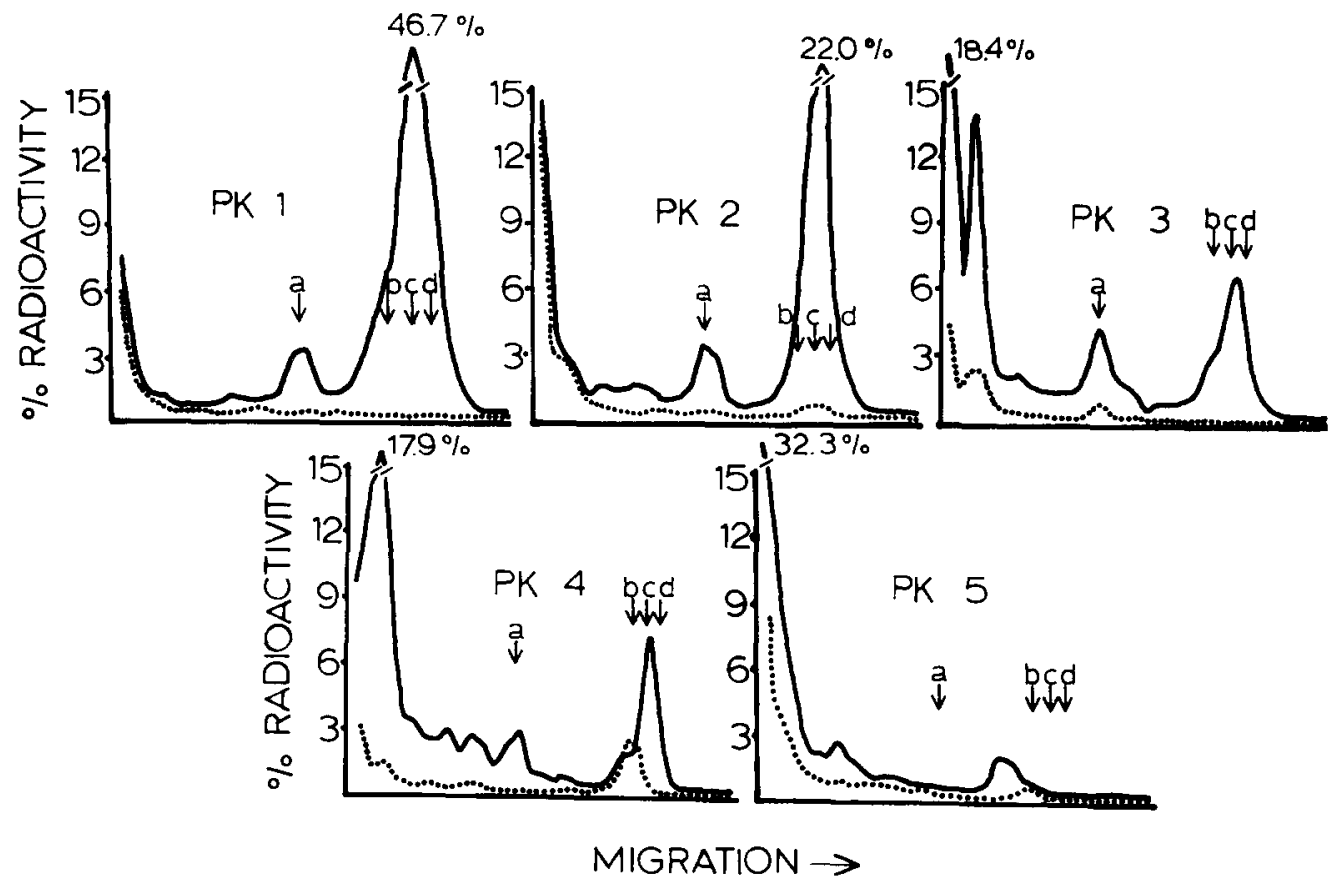

Fig. 3. Ability of kinase fractions to phosphorylate histones. Each protein kinase fraction was assayed in the presence of $\left[\gamma \cdot{ }^{32} \mathrm{P}\right] \mathrm{ATP}$ and $40 \mu \mathrm{g}$ of HeLa histone as described under Materials and Methods. After termination of the reaction, the assay mixtures were examined by polyacrylamide gel electrophoresis as described in the legend of Fig. 2 . The dotted lines represent the ${ }^{32} \mathrm{P}$ incorporation into endogenous phosphoprotein when no histone was added. Migration of histone standard $\mathrm{H} 1$ is marked by the (a) arrow, $\mathrm{H} 3$ and H3B by the (b) arrow, H2A by the (c) arrow, and $\mathrm{H} 4$ by the (d) arrow. One percent radioactivity is 103,109, 288, 1276 and $67 \mathrm{cpm}$ for PK 1, PK 2, PK 3, PK 4 and PK 5, respectively.

tion of the phosphoprotiens, as has been shown in some systems (W. Criss, pers. comm.). To address this question, the protein kinase fractions were assayed in the presence of endogenous phosphoprotein as substrate or in the presence of endogenous phosphoprotein plus histones, and following in vitro incubation in the presence of $\left[\gamma-{ }^{32} \mathrm{P}\right]$ labeled ATP, the samples were fractionated electrophoretically according to molecular weight in SDS polyacrylamide gels. The distribution of radioactivity among the various molecular weight classes of chromosomal proteins was determined and is shown in Fig. 3. The radioactivity profile induced by protein kinase fractions 1 and 2 exhibited a significant level of ${ }^{32} \mathrm{P}$ incorporation in the molecular weight region of the gel where histone standards migrate, only when histones were present in the assay. The radioactivity profile induced by protein kinase fraction 3 indicated that when histones were present in the assay mixture ${ }^{32} \mathrm{P}$ was incorporated into the histone region of the gel and in addition, 
${ }^{32} \mathrm{P}$ incorporation was increased in the higher molecular weight region of the gel. When histone was present in the assay mixtures containing protein kinase fractions 4 and 5 , very little ${ }^{32} \mathrm{P}$ incorporation was found in the histone region of the gel, however, there was a substantial increase in incorporation of ${ }^{32} \mathrm{P}$ in the higher molecular weight region.

The responsiveness of the protein kinase fractions to the cyclic nucleotides cAMP and cGMP was examined. Each fraction was assayed in the presence or absence of $5 \mu \mathrm{M}$ cAMP or cGMP, and the ${ }^{32} \mathrm{P}$ incorporated into TCA insoluble material was measured. The results are presented in Table II. There was no significant change in the total activity of any protein kinase fraction with the addition of either cAMP or cGMP. However, it was considered possible that exposure to cyclic nucleotides might alter the substrate specificity of the kinase activity. Such changes might not be

\section{TABLE II}

EFFECT OF THE PRESENCE OF CYCLIC NUCLEOTIDES ON THE ABILITY OF PROTEIN KINASE FRACTIONS TO INCORPORATE ${ }^{32} \mathrm{P}$ FROM $\left[\gamma^{32} \mathrm{P}\right]$ ATP INTO TCA INSOLUBLE MATERIAL

All assays were performed as described in Materials and Methods. Percentage of control values were calculated by assaying the fraction in the presence of $\left[\gamma^{-32} \mathrm{P}\right] \mathrm{ATP}$ and substrate (endogenous or added as indicated) with or without the cyclic nucleotide and dividing the $\mathrm{cpm}$ incorporated in the presence of the cyclic nucleotide by the cpm incorporated in its absence. Added substrate consists of $40 \mu \mathrm{g}$ of histone plus $40 \mu \mathrm{g}$ of phosphoprotein (heat-inactivated). All assays were done in duplicate and all values are the average of at least two experiments. Blank assays (containing all components except the kinase fraction) were $200-600 \mathrm{cpm}$ and assays containing kinase fractions were at least 6-10 times higher in incorporated radioactivity $t$ an blank assays. $60 \mu \mathrm{g}$ of protein kinase modulator were added where indicated.

\begin{tabular}{|c|c|c|c|c|c|}
\hline & \multicolumn{2}{|c|}{$\begin{array}{l}\% \text { of control with the } \\
\text { addition of cAMP }\end{array}$} & \multicolumn{3}{|c|}{$\begin{array}{l}\% \text { of control with the } \\
\text { addition of cGMP }\end{array}$} \\
\hline & $\begin{array}{l}\text { Endogenous } \\
\text { substrate }\end{array}$ & $\begin{array}{l}\text { Added } \\
\text { substrate }\end{array}$ & $\begin{array}{l}\text { Endo- } \\
\text { genous } \\
\text { substrate }\end{array}$ & $\begin{array}{l}\text { Added } \\
\text { substrate }\end{array}$ & $\begin{array}{l}\text { Added sub- } \\
\text { strate plus } \\
\text { protein } \\
\text { kinase } \\
\text { modulator }\end{array}$ \\
\hline $80000 \mathrm{~g}$ supernatant & 96.9 & - & - & - & $\ldots$ \\
\hline $\begin{array}{l}\text { total phosphoproteins } \\
\text { protein kinase }\end{array}$ & 103 & - & $\cdots$ & -- & $-\ldots$ \\
\hline fraction 1 & 106 & 95 & 101 & 91 & 107 \\
\hline fraction 2 & 104 & 114 & 76 & 97 & 102 \\
\hline fraction 3 & 100 & 97 & 97 & 91 & 97 \\
\hline fraction 4 & 117 & 109 & 107 & 103 & 101 \\
\hline fraction 5 & 100 & 113 & 101 & 88 & 91 \\
\hline
\end{tabular}




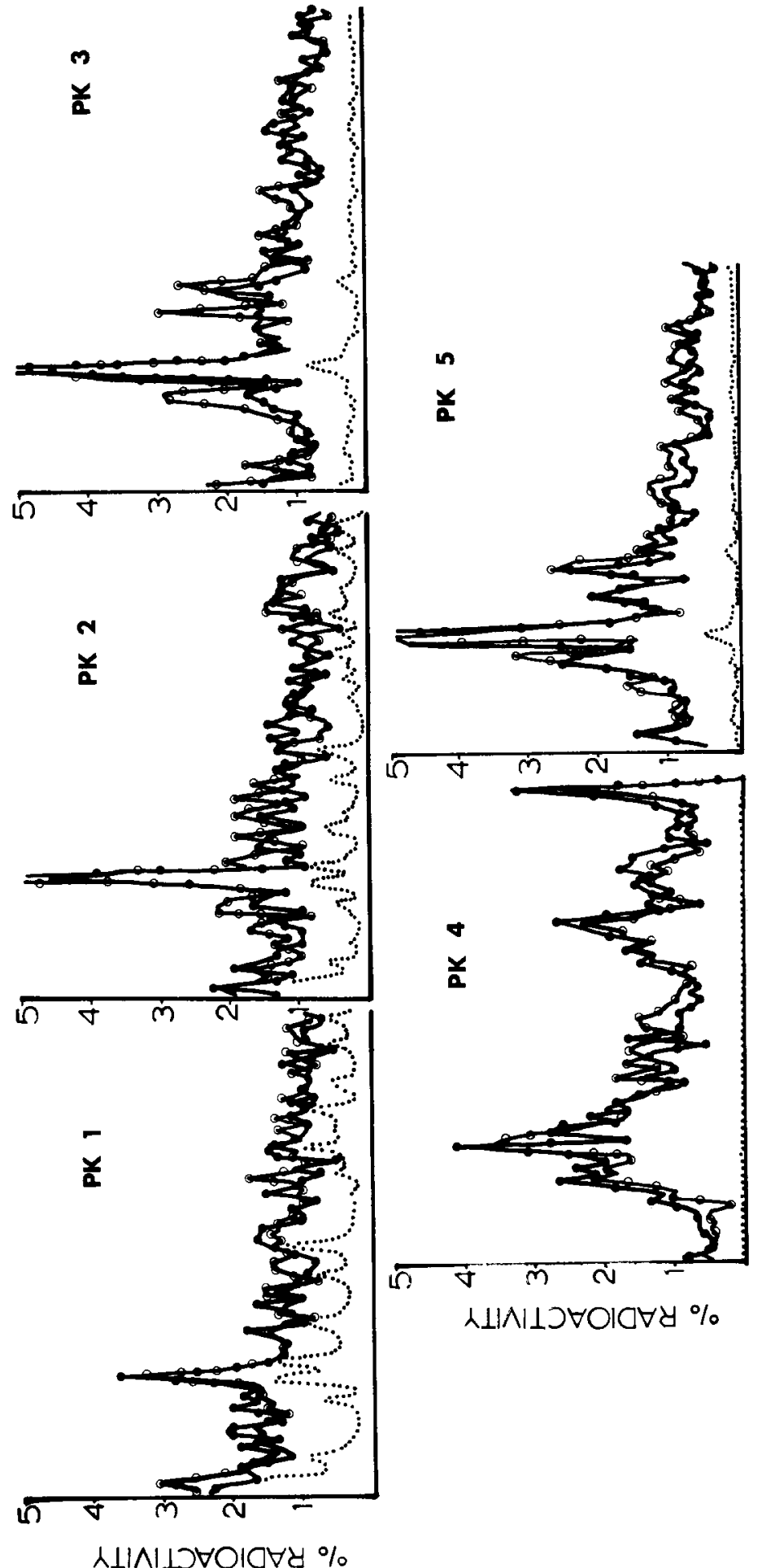

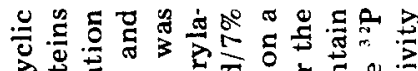

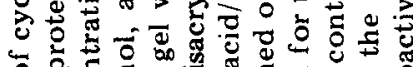
o \&

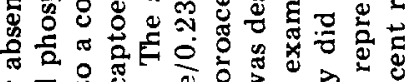

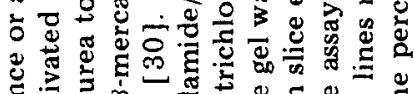

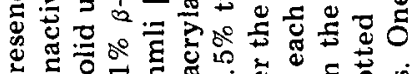
东

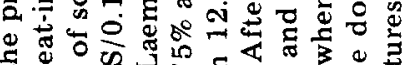

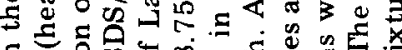
马

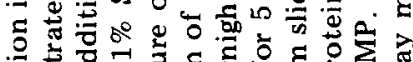

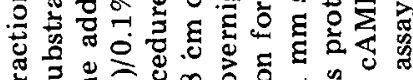
娄落

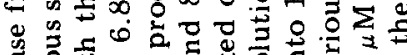

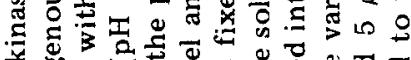
政

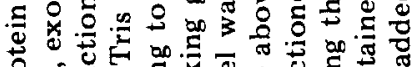

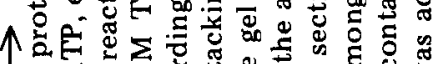

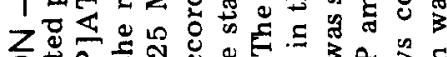

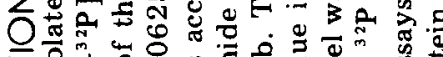

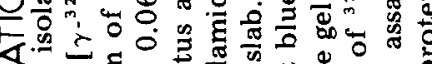

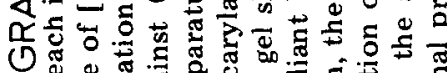

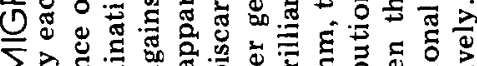

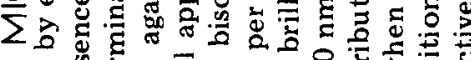

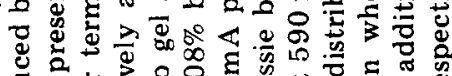
ร

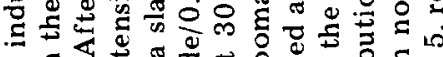

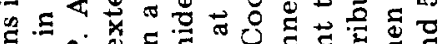

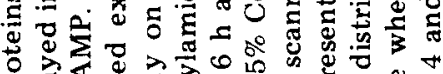
娚 N

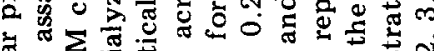
б उ 00 0

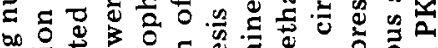

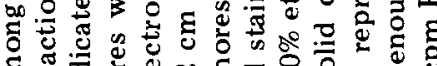

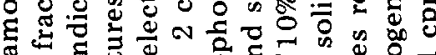
के

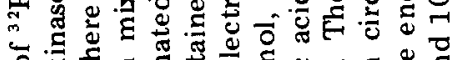

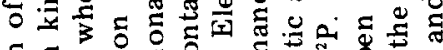

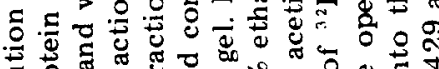

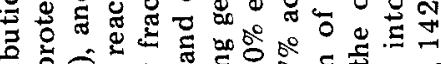

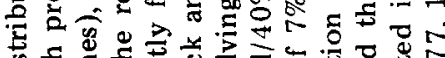

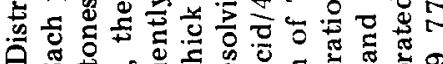

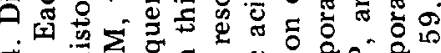

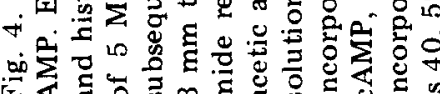




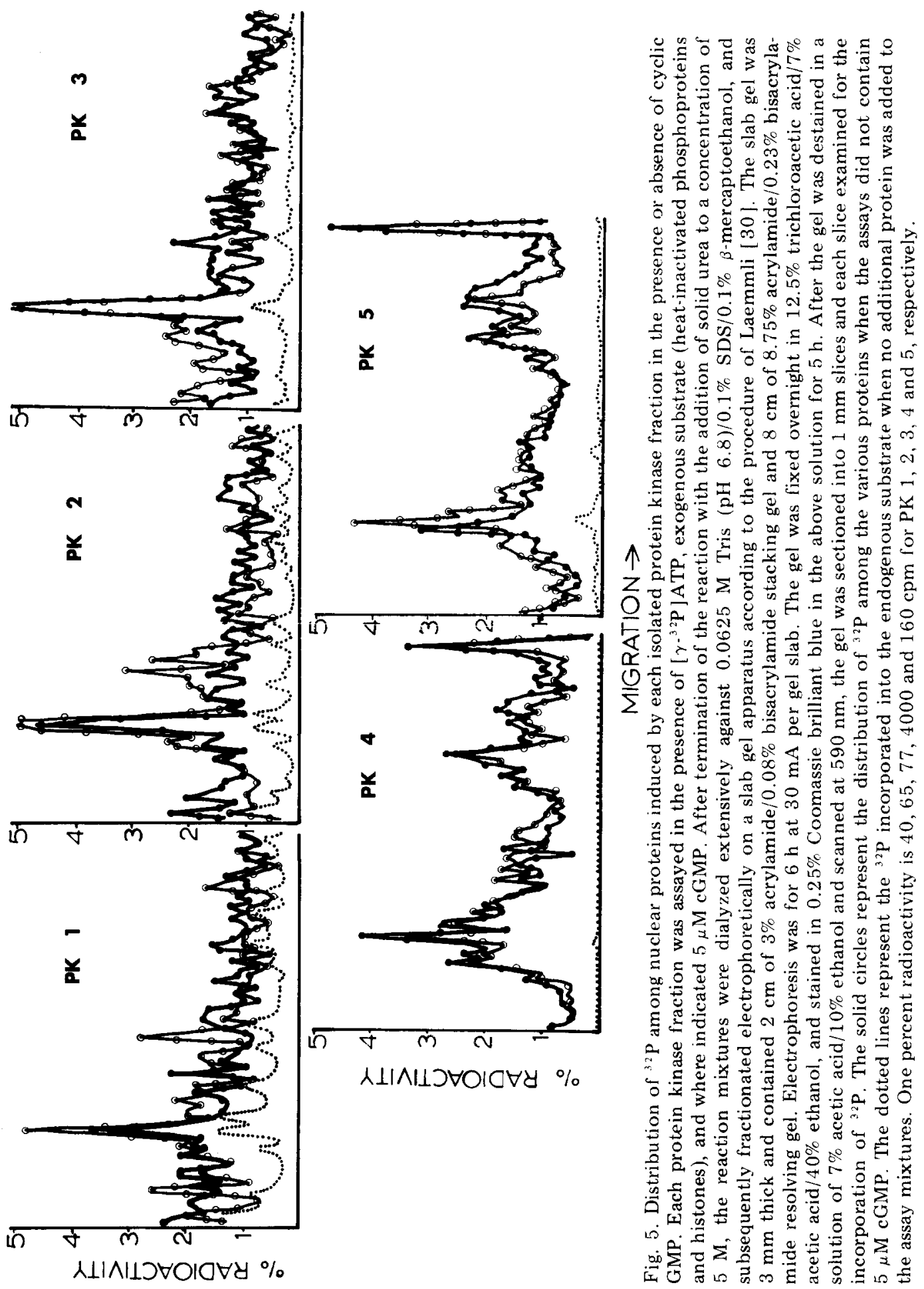


observed in measurements of ${ }^{32} \mathrm{P}$ incorporation into TCA-insoluble material. To examine this possibility, each fraction was assayed with exogenous substrate and $\left[\gamma_{-}{ }^{32} \mathrm{P}\right] \mathrm{ATP}$ in the presence or absence of cAMP and in the presence or absence of cGMP, and assay mixtures were examined by polyacrylamide gel electrophoresis. The distribution of ${ }^{32} \mathrm{P}$ radioactivity among the various molecular weight classes of nuclear proteins was determined. Slab gel electrophoresis (using the method of Laemmli [30]) was utilized to afford better resolution and therefore increase the possibility of detecting small changes. No distinct differences in the phosphorylation of nuclear proteins could be seen with the addition of the cyclic nucleotides, as is shown in Figs. 4 and 5.

Protein factors have been shown to alter the sensitivity of kinases to cyclic nucleotides [ $31-33]$, and there are reports of a protein kinase modulator which dramatically increases the responsiveness of cGMP-sensitive protein kinases to cGMP. This heat-stable protein has been shown to increase 2-5-fold the cGMP stimulation of cGMP-sensitive protein kinases in vitro. The mechanism of this stimulation is not yet understood. Our protein kinase fractions were assayed in the presence of this protein kinase modulator in order to investigate fully the cyclic nucleotide sensitivity of the protein kinase fractions The protein kinase fractions were assayed in the presence of protein kinase modulator isolated from dog heart as described by Appleman [26]. The ${ }^{32} \mathrm{P}$ incorporation into TCA insoluble material was measured. Even in the presence of protein kinase modulator, however, no significant response to cGMP could be detected in any of the protein kinase fractions. The results are presented in Table II.

\section{DISCUSSION}

The role that phosphorylation of nuclear protein plays in the complex mechanisms involved in the control of gene regulation in eukaryotic organisms has recently been receiving considerable attention. Nuclear phosphoproteins have been shown to possess the characteristics that one would expect of molecules whose function is involved in the modulation of gene expression. These characteristics include tissue and species specificity [34-36], changes throughout the cell cycle $[7,10,37,38]$, the ability to bind to homologous DNA high rates of turnover, changes correlated with the metabolic state of the cell, and changes in both protein species and degree of phosphorylation induced by a variety of gene-activating stimuli such as hormones $[3,6,11,39]$. Differences in the phosphorylation of nuclear proteins have also been demonstrated during carcinogenesis $[5,40]$ and viral transformation [41]. More direct evidence for the involvement of nuclear phosphoproteins in the control of gene transcription is suggested by studies concerned with the control of the histone genes in $\mathrm{HeLa} \mathrm{S}_{3}$ cells. In this system evidence has been presented which suggests that a component of the nuclear phosphoproteins isolated from $\mathrm{S}$ phase HeLa cells may be 
involved with determining the availability of histone genes from transcription. Other results suggest that the ability of $\mathbf{S}$ phase chromatin to transcribe the histone genes in vitro can be reduced $70 \%$ by enzymatic partial dephosphorylation of the non-histone chromosomal proteins [12].

In intact cells the nuclear phosphoproteins are enzymatically phosphorylated and dephosphorylated by protein phosphokinases and protein phosphatases respectively, which are present in the nucleus $[4,14,16-23]$. It is possible that phosphoproteins can function as modulators of gene expression only when they are in a specific state of phosphorylation. The presence of specific phosphoproteins in the nucleus may not by itself determine availability or nonavailability of specific genes for transcription but rather the controlling factor might rest with the enzymes that are responsible for the phosphorylation or dephosphorylation of these proteins. Several investigators have studied nuclear protein kinases in various tissues [14,16,17,19-22], but only a few have demonstrated significant heterogeneity of the kinases $[18,23]$ or have investigated any correlations of kinase activity with various biological conditions such as neoplasia $[23,42,43]$. Also only limited studies have been directed toward nuclear protein kinases in tissue culture cells $[44-66]$. We have therefore begun to isolate and partially characterize the nuclear protein kinase fractions from HeLa $S_{3}$ cells, which the aim of studying variations in nuclear protein kinases and their activities during the cell cycle.

A method of fractionation of nuclear protein kinase activity using gradient elution was employed by Kish and Kleinsmith [18] to obtain 12 fractions of kinase activity from calf thymus nuclear phosphoproteins. However in HeLa $\mathrm{S}_{3}$ colls, due to limited availability of material, a stepwise elution gradient was employed. It is possible with this methodology to isolate 5 reproducible fractions of kinase activity from the nuclei of HeLa $\mathrm{S}_{3}$ cells. However each fraction does not necessarily contain only one kinase. The majority of the activity recovered was found in fractions 3,4 and 5 which were eluted with $0.05 \mathrm{M}$ Tris $(\mathrm{pH} 7.5)$ containing $0.5,0.7$ and $0.9 \mathrm{M}$ $\mathrm{NaCl}$, respectively. Fraction 4 exhibited the highest percentage of recovered activity. This fraction has been shown in other systems to be substantially increased in activity in highly proliferating tissues [23]. All 5 kinase fractions differed with respect to specific activity, optimum $\mathrm{Mg}^{2+}$ concentration and substrate specificity, indicating that the fractions represented different species of kinase activity. However, the possibility should not be dismissed that protein factors or sub-units may be shared by various nuclear protein kinase fractions that we have identified. It should be noted that an additional small peak of activity with characteristics similar to those of the tumor-associated enzyme peak described in other systems [23] was occasionally eluted with the $0.3 \mathrm{M} \mathrm{NaCl}$ buffer. Since this peak was found only occasionally, it was not possible to characterize it in the manner that was used in the study of the other fractions. Based on the absence of cytoplasmic material in our nuclear preparations, it is unlikely that significant 
amounts of cytoplasmic protein kinase were present in our nuclear protein kinase fractions. However, because nuclei were subjected to aqueous solutions during isolation, some loss of nuclear protein kinases may be a possibility.

Considering the importance of cyclic nucleotides to the activity of many cytoplasmic protein kinases the 5 fractions were analyzed for their responsiveness to CAMP and CGMP. It would have been of interest to have observed any response to cGMP since it has been shown that the concentrations of cGMP increases during the entry of the cell into mitosis [47]. However, no response was seen in any protein kinase fraction to either cAMP or cGMP, even in the presence of protein kinase modulator which is thought to be necessary to observe stimulation of some protein kinases by cGMP [31]. This is in agreement with many other reports concerning nuclear kinases [16 21,48,49]. However, a regulatory subunit may be lost in the preparation of the phosphoprotein; if so, this subunit must be lost in the initial isolation steps involving high salt extraction since the supernatant of the first centri fugation after this extraction shows no change in kinase activity when exposed to cyclic nucleotides. Additionally the possibility cannot be dismissed that due to the heterogeneity of the enzyme fractions and substrates cyclic nucleotide dependent alterations in protein kinase activity may be masked. The absence of a response of our nuclear kinases to cyclic nycleotides is consistent with the absence of cytoplasmic protein kinases in the nuclear phosphoprotein preparation, the cyclic nucleotide dependence of cy toplasmic protein kinases has clearly been documented.

Although our nuclear protein kinase fractions do not appear to be responsive to cyclic nucleotides, it is possible that the kinases themselves may be activated by other cyclic AMP-dependent protine kinases -- nuclear or cytoplasmic. Recent results suggest that in several biological systems, protein kinases which do not require cyclic AMP for their catalytic activity must initially be phosphorylated by a cyclic AMP-dependent protein kinase [50]. Having obtained some degree of fractionation of the HeLa nuclear protein kinases and accumulated information concerning their characteristics, studies are now underway to investigate these enzymes under various biological conditions It is anticipated that further study of these enzymes will offer insight into the interrelationship of phosphorylation of nuclear proieins and the control of gene expression in eukaryotic cells.

\section{ACKNOWLEDGEMENT}

These studies are supported by Grant No. GM20535 from the National Institutes of Health.

\section{REFERENCES}

1 Elgin, S. and H. Weintraub: Annu. Rev. Biochem. 44, 725-774 (1975). 
2 Stein, G.S., T.C. Spelsberg and L.J. Kleinsmith: Science 183, 817. 824 (1974).

2 Alumed, K. and H. Ishida: Mol. Pharmacol. 7, 323--327 (1971).

4 Brade, W.P., J.A. Thomson, J.-F. Chiu and L.S. Hnilica: Exp. Cell Res. 84, 183-190 (1974).

5 Chiu, J.-F., C. Craddock, S. Getz and L.S. Hnilica: FEBS Lett. 33, 247-250 (1973).

6 Jungman, R.A. and J.S. Schweppe: J. Biol. Chem. 247, 55355542 (1972).

7 Karn, J., E.M. Johnson, G. Vidali and V.G. Allfrey: J. Biol. Chem. 249, 667 677 (1974).

8 Kleinsmith, L.: J. Cell. Physiol. 85, 459-475 (1975).

9 Krause, M.O., L.J. Kleinsmith and G.S. Stein: Exp. Cell Res. 92, 164- 174 (1975).

10 Platz, R., G. Stein and L. Kleinsmith, Biochem. Biophys. Res. Comm. 51, 735 740 (1973).

11 Turkington, R.W. and M. Riddle: J. Biol. Chem. 244, 6040-6046 (1969).

12 Kleinsmith, L.J., J.L. Stein and G.S. Stein: Proc. Natl. Acad. Sci. U.S.A. 73, 1174 $1178(1976)$.

13 Thomson, J.A., J.L. Stein, L.J. Kleinsmith and G.S. Stein, Science 194, 428432 (1976).

14 Desjardins, P.R., P.F. Lue, C.C. Ljew and A.G. Gornall: Can. J. Biochem. 50, $1249-$ 1259 (1972).

15 Farron-Furstenthal, F. and J.R. Lightholder: FEBS Lett. 84, 313 316 (1977).

16 Gibson, K., L. Tichonicky and J. Kruh: Biochimie 56, 1417-1423 (1974).

17 Kamiyama, M. and T.Y. Wang: Biochim. Biophys. Acta 228, 563-576 (1971)

18 Kish, V.M. and L.J. Kleinsmith, J. Biol. Chem. 249, 750-760 (1974).

19 Kruh, J.B., N. Dastugue, M. Defer, M. Kamiyama and L. Tichonicky: 56, 995-1001 (1974).

20 Rikans, L.E. and R.W. Ruddon, Biochem. Biophys. Res. Comm. 54, 387- 394 (1973).

21 Rikans, L.E. and R.W. Ruddon, Biochim. Biophys. Acta 422, $73-86$ (1976).

22 Takeda, M.S., S. Matsumura and Y. Nakaya, J. Biochem. 75, 743-751 (1974).

23 Thomson, J.A., J.-F. Chiu and L.S. Hnilica, Biochim. Biophys. Acta 407, 114 119 (1975).

24 Thornburg, W. and T.J. Lindell, J. Biol. Chem. 252, 6660-6665 (1977).

25 Keilen, D. and E.F. Hartree, Proc. R. Soc. London Ser. B 124, 397 405 (1938)

26 Appleman, M.M., L. Birnbaumer and H.N. Torros, Biophysics 116, 39- 43 (1966).

27 Glynn, I.M. and J.B. Chappell, Biochem. J. 90, 147-149 (1964).

28 Langan, T.A.: In: Regulation of nucleic acid and protein biosynthesis, eds. Koningsberger and Bosch (Elsevier, Amsterdam) pp. 233--242 (1967).

29 Kleinsmith, L.J.. In Acidic proteins of the nucleus, eds. Cameron and Jeter, jr. (Academic Press, New York) p. 103 (1974).

30 Laemmli, U.: Nature 227, 680-685 (1970).

31 Donnelly, T.E., jr., J.F. Kuo, P.L. Reyes, Y.-P. Liu and P. Grungard, J. Biol. Chem. 248, 190- 198 (1971).

32 Kuo, J.F. and P. Greengard, Fed. Proc. 30, 1089Abs (1971).

33 Walsh, D.A., C.D. Ashby, D. Gonzalez, D. Calkins, E.H. Fischer and E.G. Krebs: J. Biol. Chem. 246, 19771985 (1971).

34 Gronow, M. and T. Thackrah: Arch. Biochem. Biophys. 158, 377-386 (1973).

35 Platz, R.D., V.M. Kish and L.J. Kleinsmith, FEBS Lett. 12, 38-40 (1970).

36 Wu, F.C., S.C.R. Elgin and L.E. Hood: Biochemistry 12, 2692-2797 (1973).

27 deMorales, M.M., C. Blat and L. Harel: Exp. Cell Res. 86, 111-119 (1974).

38 Gerner, E.W. and R.M. Humphrey: Biochim. Biophys. Acta 331, 117 127 (1973).

39 Bottıms, G.S. and R.A. Jungmann, Proc. Soc. Exp. Biol. Med. 144, 83-88 (1973).

40 Chiu, J.-F., W.P. Brade, J.A. Thomson, Y.-H. Tsai and L.S. Hnilica, Exp. Cell Res. 91.200 206 (1975).

41 Krayse, M.O. L.J. Kleinsmith and G.S. Stein, Life Sci. 16, 1047-1058 (1975).

42 Farron-Furste :thal, F.: Biochem. Biophys. Res. Comm. 67, 307-314 (1975). 
43 Farron-Furstenthal, F. and J.R. Ligh tholder, In: Onco-developmental gene expression, eds. Fishman and Sell (Academic Press, New York) pp. 57-64 (1976).

44 Blat, C., M.M. deMorales and L. Harel. Exp. Cell Res. 98, 104-110 (1976).

45 Costa, M., D.J.M. Fuller, D.H. Russell and E.W. Gerner, Biochim. Biophys. Acta 479, $416-426(1977)$

46 Kruh, J., Y. Courtois and L. Tichonicky: Biochimie 57, 1323-1329 (1975).

47 Seifert, W.E. and P.S. Rudland, Nature 248, 138-140 (1974).

48 Siebert, G., M.G. Ord and L.A. Stocken: Biochem. J. 122, 721-725 (1971).

49 Wilson, M.J. and K. Ahmed, Exp. Cell Res. 93, 261-266 (1975).

50 Datta, A., C. DeHaro, J.M. Sierra and S. Ochoa: Proc. Natl. Acad. Sci. U.S.A. 74, 1463-1467 (1977).

51 Layne, E.: Methods Enzymol. 3, 447-454 (1957).

52 Bhorjee J.S. and T. Pederson: Biochemistry 12, 2766-2773 (1973). 